\title{
PENGARUH KEPEMILIKAN MANAJERIAL, INSTITUSIONAL DAN KOMITE AUDIT TERHADAP PENGUNGKAPAN CORPORATE SOCIAL RESPONSIBILITY
}

\author{
Padma Adriana Sari'1, Berlia Tri Handini ${ }^{2}$ \\ Politeknik Negeri Malang1,2 \\ Jl. Soekarno Hatta No. 9 Malang, 65141, Indonesia \\ e-mail:padma.adriana.sari@gmail.com ${ }^{1}$, nonaberlia28@gmail.com²
}

\begin{abstract}
This study aims to analyze the influence of managerial ownership, institutional ownership and audit committee on the disclosure of Corporate Social Responsibility. The population in this study is consumer goods industry company registered in the Indonesian Stock Exchange period 2014 to 2018. The research sample was selected using purposive sampling method with a total of 16 companies and a period of 4 years. The research uses quantitative methods with multiple linear regression methods. The results showed that managerial ownership had no significant effect on CSR disclosure, institutional ownership had a significant positive effect on CSR disclosure and audit committees had a significant positive effect on CSR disclosure.
\end{abstract}

Keywords : Managerial Ownership, Institutional Ownership, Audit Committee, CSR Disclosure

\begin{abstract}
Abstrak
Penelitian ini bertujuan untuk menganalisis pengaruh kepemilikan manajerial, kepemilikan institusional dan komite audit terhadap pengungkapan Corporate Sosial Responsibility. Populasi pada penelitian ini adalah perusahaan industri barang konsumsi yang terdaftar di Bursa Efek Indonesia periode 2014 sampai dengan 2018. Sampel penelitian dipilih menggunakan metode purposive sampling dengan total perusahaan sejumlah 16 perusahaan dan periode 4 tahun. Penelitian menggunakan metode kuantitatif dengan metode regresi linier berganda. Hasil penelitian menunjukkan bahwa kepemilikan manajerial tidak berpengaruh signifikan terhadap pengungkapan CSR, kepemilikan institusional berpengaruh signifikan positif terhadap pengungkapan CSR dan komite audit berpengaruh signifikan positif terhadap pengungkapan CSR.
\end{abstract}

Kata Kunci : Kepemilikan manajerial, Kepemilikan Institusi, Komite Audit, Pengungkapan CSR

\section{PENDAHULUAN}

Seiring perkembangan zaman yang modern, isu tentang Corporate Social Responsibility semakin sering dibahas. Pengungkapan Corporate Social Responsibility (CSR) tumbuh secara luas dalam bisnis di banyak negara, termasuk juga di Indonesia. CSR merupakan tanggapan perusahaan dari kesadaran masyarakat mengenai beberapa isu-isu sosial seperti polusi, limbah, menipisnya sumber daya, kualitas produk dan keamanan serta hak-hak dan status pekerja (Gray, et al., 1995 dalam Bawono \& Haryanto, 2015). Pelaporan CSR memberikan manfaat kepada masyarakat berupa informasi pelaksanaan aktivitas sosial oleh perusahaan sehingga masyarakat dapat memperoleh haknya untuk hidup aman, karyawan memperoleh kesejahteraan dan semua pihak 
Berlia Tri Handini dan Padma Adriana Sari: Pengaruh Kepemilikan Manajerial, Institusional dan Komite Audit Terhadap Pengungkapan CSR

memperoleh keamanan untuk mengkonsumsi atau menggunakan produk perusahaan.

Telah ada peraturan undang-undang yang mewajibkan perusahaan di Indonesia untuk melaksanakan dan melaporkan kegiatan CSR. Adanya peraturan tersebut dapat memaksa perusahaan untuk melaporkan pertanggungjawaban sosialnya (Purwanto, 2011). Pertanggungjawaban pengungkapan CSR yang dilakukan perusahaan harus memberikan informasi yang sesuai dengan praktik yang dilakukannya, karena laporan tersebut nantinya akan menjadi pertimbangan investor dan masyarakat dalam menilai peran sebuah perusahaan dalam memenuhi tanggung jawab sosialnya.

Berbagai penelitian terkait faktor-faktor yang dapat mempengaruhi pengungkapan CSR telah banyak dilakukan. Salah satu faktor yang telah diteliti adalah struktur kepemilikan perusahaan. Struktur kepemilikan dinilai dari struktur kepemilikan saham, yaitu perbandingan jumlah saham yang dimiliki oleh orang dalam (insider) dengan jumlah saham yang dimiliki oleh investor (Sugiarto, 2009, p. 59). Dapat dikatakan pula struktur kepemilikan saham adalah proporsi kepemilikan institusional dan kepemilikan manajemen dalam kepemilikan saham perusahaan. Dua jenis kepemilikan perusahaan yang banyak diteliti adalah kepemilikan manajerial dan kepemilikan institusional.

Penelitian yang dilakukan oleh Nurleni, dkk. (2018) mengungkapkan bahwa kepemilikan manajerial memiliki pengaruh negatif signifikan terhadap pengungkapan CSR. Hal ini berarti bahwa semakin rendah kepemilikan saham perusahaan oleh manajemen perusahaan, maka akan semakin tinggi pengungkapan CSR yang dilakukan perusahaan. Namun dalam penelitian Listyaningsih dkk. (2018), Singal \& Putra (2019) serta Anissa \& Machdar (2019) ditemukan hasil yang berbeda, yaitu adanya pengaruh positif dan signifikan dari kepemilikan manajerial terhadap pengungkapan CSR. Hal ini berarti bahwa semakin tinggi kepemilikan saham perusahaan oleh manajemen perusahaan, maka akan semakin tinggi pengungkapan CSR yang dilakukan perusahaan. Sementara dalam penelitian Sari \& Rani (2015), kepemilikan manajerial ditemukan tidak memiliki pengaruh signifikan terhadap pengungkapan CSR. Penelitian-penelitian ini menunjukkan hasil yang tidak konsisten mengenai pengaruh kepemilikan manajerial terhadap pengungkapan CSR.

Selain kepemilikan manajerial, faktor yang banyak diteliti pengaruhnya terhadap pengungkapan CSR adalah kepemilikan institusional. Bernandhi \& Muid (2014), menerangkan bahwa kepemilikan institusional adalah kepemilikan saham suatu perusahaan oleh institusi atau lembaga seperti perusahaan asuransi, bank, perusahaan investasi, dan kepemilikan institusi lainnya. Semakin terkonsentrasi kepemilikan saham dalam suatu perusahaan, maka pengawasan yang dilaksanakan oleh pemilik akan semakin efektif dan efisien sebab manajemen akan semakin berhati-hati bekerja untuk pemilik modal (Sujoko, et al., 2007 dalam Rahma, 2014).

Faktor kepemilikan institusional pada penelitian terdahulu juga memberikan hasil yang kurang konsisten. Penelitian yang dilakukan oleh Sari \& Rani (2015) mengungkapkan bahwa kepemilikan institusional berpengaruh negatif signifikan terhadap pengungkapan CSR. Hasil yang sama juga ditemukan dalam penelitian Anissa 
Berlia Tri Handini dan Padma Adriana Sari: Pengaruh Kepemilikan Manajerial, Institusional dan Komite Audit Terhadap Pengungkapan CSR

\& Machdar (2019). Hal ini berarti bahwa semakin rendah kepemilikan saham perusahaan oleh institusi di luar perusahaan maka akan semakin tinggi pengungkapan CSR yang dilakukan perusahaan. Namun dalam penelitian Nugroho \& Yulianto (2015), Jaya dkk. (2017), Listyaningsih, dkk. (2018), Nurleni, dkk. (2018), serta Singal \& Putra (2019) ditemukan hasil yang berbeda, yaitu adanya pengaruh positif dan signifikan dari kepemilikan institusional terhadap pengungkapan CSR. Sementara dalam penelitian Iswandika, Murtanto \& Sipayung (2014), kepemilikan institusional ditemukan tidak memiliki pengaruh signifikan terhadap pengungkapan CSR.

Selain struktur kepemilikan saham, variabel lain yang juga banyak diteliti pengaruhnya terhadap pengungkapan CSR adalah komite audit. Adanya komite audit diharapkan dapat mendukung kinerja dewan komisaris pada pengungkapan laporan tanggung jawab sosial perusahaan (Erawati dan Sari, 2021). Penelitian yang dilakukan oleh Putra \& Rivandi (2019) dan Iswandika, et al. (2014) memberikan hasil bahwa komite audit berpengaruh positif dan signifikan terhadap pengungkapan CSR. Hal ini berarti bahwa keberadaan komite audit dengan jumlah anggota yang sesuai dengan aturan yang ada akan meningkatkan pengungkapan CSR yang dilakukan perusahaan. Namun hasil yang sebaliknya ditemukan dalam penelitian Rizki, Basri \& Musnadi (2014), yaitu komite audit berpengaruh negatif signifikan terhadap pengungkapan CSR. Hal ini berarti bahwa keberadaan komite audit dengan jumlah anggota yang sesuai dengan aturan yang ada justru menurunkan pengungkapan CSR. Sementara dalam penelitian Nugroho \& Yulianto (2015) maupun Listyaningsih, et al. (2018), komite audit ditemukan tidak berpengaruh signifikan terhadap pengungkapan CSR.

Perusahaan manufaktur adalah salah satu jenis perusahaan yang banyak menghasilkan limbah dalam proses produksi yang dilaksanakannya. Oleh karena itu, perusahaan manufaktur memiliki kontribusi yang besar dalam masalah-masalah seperti kerusakan lingkungan, polusi, limbah, keamanan produk maupun tenaga kerja.

Salah satu perusahaan manufaktur yang sering menghadapi masalah pencemaran lingkungan adalah industri barang konsumsi. Perusahaan ini mengolah bahan mentah menjadi barang jadi untuk dikonsumsi atau dipakai masyarakat dalam memenuhi kebutuhannya sehari-hari. Beberapa contoh kasus pencemaran lingkungan yang terjadi pada industri barang konsumsi yaitu pencemaran limbah susu oleh PT. Greenfield di sungai Lekso Kecamatan Wlingi tahun 2020 (Riady, 2020), pencemaran sungai dari limbah pabrik bakso di wilayah Bogor (Heriyanto,2020) dan PT. Siantar Top yang membuang air limbah pabrik ke dalam sungai (Erawati dan Sari, 2021). Selain itu, di tahun 2019 isu pencemaran laut menjadi isu yang ramai dibahas dalam Forum Ekonomi Dunia di Davos, Swiss (Riyadi, 2019). Pada forum tersebut dinyatakan bahwa perusahaan consumer goods telah mencemari laut dengan sampah plastik yang mereka gunakan.

Pengungkapan CSR penting untuk dilakukan oleh perusahaan industri barang konsumsi karena persepsi masyarakat atas citra perusahaan cenderung berpengaruh terhadap penjualan produk. Industri ini diharapkan untuk menunjukkan perhatian yang besar kepada masyarakat dengan melakukan pengungkapan tanggung jawab sosial sehingga dapat meningkatkan image perusahaan dan dapat memberikan pengaruh pada 
Berlia Tri Handini dan Padma Adriana Sari: Pengaruh Kepemilikan Manajerial, Institusional dan Komite Audit Terhadap Pengungkapan CSR

penjualan. Pelaksanaan program CSR memang tidak secara langsung menghasilkan keuntungan bagi perusahaan. Namun pengungkapan CSR tersebut dapat memberikan banyak manfaat bagi perusahaan yaitu meningkatkan citra perusahaan dan menciptakan lingkungan sosial yang lebih baik sehingga memberikan manfaat jangka panjang bagi perusahaan.

Penelitian ini merupakan pengembangan dari penelitian sebelumnya oleh Nurleni, Bandang, Darmawati \& Amiruddin (2018). Perbedaan penelitian ini dengan penelitian sebelumnya adalah:

1. Tahun pengamatan pada penelitian sebelumnya adalah tahun 2011-2015 dengan sampel perusahaan manufaktur yang terdaftar di BEI, sedangkan pada penelitian ini tahun yang digunakan adalah 2014-2018 pada perusahaan sektor industri barang konsumsi yang terdaftardi BEI.

2. Penelitian sebelumnya meneliti tentang pengaruh struktur kepemilikan yang terdiri dari kepemilikan manajerial dan kepemilikan institusional terhadap pengungkapan corporate social responsibility (CSR), sedangkan pada penelitian ini ditambahkan 1 variabel lagi yaitu komite audit.

Berdasarkan uraian di atas, terdapat hasil yang belum konsisten pada penelitian sebelumnya mengenai pengaruh kepemilikan manajerial, kepemilikan institusional, dan komite audit terhadap pengungkapan CSR. Selain itu telah dibahas juga mengenai pentingnya pengungkapan CSR pada perusahaan industri barang konsumsi. Oleh karena itu penelitian ini bertujuan untuk mengetahui dan menganalisis pengaruh kepemilikan manajerial, kepemilikan institusional dan komite audit terhadap pengungkapan CSR pada perusahaan sektor consumer goods industry yang terdaftar di Bursa Efek Indonesia Tahun 2014-2018.

\section{KAJIAN PUSTAKA}

\section{Corporate Social Responsibility (CSR)}

Pertanggungjawaban sosial perusahaan atau Corporate Social Responsibility (CSR) adalah kepedulian perusahaan menyisihkan sebagian keuntungan (profit) bagi kepentingan pembangunan manusia(people) dan lingkungan (planet) secara berkelanjutan berdasarkan prosedur (procedure) yang tepat dan professional (Suharto, 2010, p. 102). Sedangkan menurut Mardikanto (2014), tanggungjawab sosial adalah sebuah konsep dimana perusahaan mengintegrasikan kepedulian sosial dan lingkungan dalam operasi bisnis dan dalam interaksi dengan para pemangku kepentingan secara sukarela yang mengarah pada keberhasilan bisnis yang berkelanjutan ( $p$. 127).

Corporate Social Responsibility secara umum berarti melakukan bisnis dengan cara yang etis dan untuk kepentingan masyarakat luas, menanggapi dengan positif dan mengutamakan harapan prioritas sosial yang muncul, menyeimbangkan kepentingan pemegang saham terhadap kepentingan masyarakat luas serta menjadi warga negara yang baik di masyarakat. Dengan kata lain Corporate Social Responsibility adalah tentang kewajiban organisasi untuk semua stakeholder, bukan hanya pada pemegang saham. 
Berlia Tri Handini dan Padma Adriana Sari: Pengaruh Kepemilikan Manajerial, Institusional dan Komite Audit Terhadap Pengungkapan CSR

Menurut Mardikanto (2014), dimensi Corporate Social Responsibility dibagi menjadi 3 (tiga) yaitu Dimensi Ekonomi Pemahaman terhadap dimensi ekonomi corporate social responsibility, meliputi: Tata kelola perusahaan, Perlindungan Konsumen, dan Etika investasi; Dimensi Sosial, Dimensi sosial diartikan sebagai perusahaan harus berpartisipasi dalam mencapai kesejahteraan masyarakat, dam dalam memperbaiki serta merawat urusan karyawannya Kerja Adil dan Praktik Kerja, serta kontribusi terhadap masyarakat setempat; Dimensi Lingkungan Kewajiban perusahaan terhadap dampak lingkungan yang dihasilkan dari operasi dan produk, menghilangkan emisi, limbah mencapai efisiensi maksimum dan produktivitas tergantung pada sumber daya yang tersedia, penurunan praktik yang dapat berdampak negatif terhadap negara dan ketersediaan sumber daya generasi berikutnya ( $p$. 149-150).

\section{Pengungkapan Corporate Social Responsibility (CSR)}

Di Indonesia pengungkapan pertanggungjawaban sosial merupakan praktik pengungkapan yang wajib dilaksanakan karena telah diatur dalam peraturan dan perundang-undangan (Purwanto, 2011, p. 18). Isi dari pengungkapan pertanggung jawaban sosial pun telah diatur oleh Bapepam melalui Kep-431/BL/2012. Melalui peraturan Bapepam perusahaan yang menyampaikan laporan tahunannya diminta untuk memasukkan bahasan mengenai tanggung jawab sosial meliputi kebijakan, jenis program dan biaya yang dikeluarkan terhadap aspek yang berhubungan dengan lingkungan hidup, praktik ketenagakerjaan, pengembangan sosial dan kemasyarakatan serta tanggung jawab produk.

CSR dalam praktik yang dilakukan perusahaan tidak selamanya dapat terealisasi dengan baik karena berbagai pengaruh. Menurut Prince of Wales Foundation ada lima hal yang dapat mempengaruhi implementasi CSR yaitu human capital atau pemberdayaan manusia, lingkungan, good corporate governance, social cohesion atau tidak menimbulkan kecemburuan sosial dan terakhir adalah memberdayakan lingkungan menuju kemandirian di bidang ekonomi (Untung, 2008, p. 11). Pengaruh-pengaruh tersebut diharapkan dapat diatasi oleh perusahaan agar tercapai sustainability development. Sustainabilty development merupakan konsep yang diperkenalkan oleh The Brutndland Commision yang kemudian memberikan dampak besar kepada perkembangan CSR. Perkembangan tersebut memunculkan konsep lain yang disebut sebagai sustainibility report. Sustainability report adalah media pengungkapan CSR yang berisi laporan mengenai kebijakan ekonomi, lingkungan dan sosial, pengaruh dan kinerja organisasi dan produknya dalam konteks pembangunan berkelanjutan. Sustainability report membantu perusahaan dalam mengukur kinerja demi mencapai tujuan pembangunan berkelanjutan, sehingga perusahaan dan pihak eksternal dapat memahami dan mengelola dampak keberlanjutan dari perusahaan tersebut.

\section{HIPOTESIS}

\section{Pengaruh Kepemilikan Manajerial terhadap Pengungkapan CSR}

Tingkat konsentrasi kepemilikan manajerial memiliki implikasi penting bagi manajer untuk bertindak pada kepentingan terbaik demi maksimalisasi nilai mereka 
Berlia Tri Handini dan Padma Adriana Sari: Pengaruh Kepemilikan Manajerial, Institusional dan Komite Audit Terhadap Pengungkapan CSR

sendiri (Ahmed, 2009). Dalam membuat keputusan-keputusan perusahaan, manajer dapat bertindak mewakili kepentingan pribadinya atau mewakili kepentingan para pemegang saham. Kesalahan yang biasanya muncul pada saat manajer membuat keputusan adalah mengenai dampak dari keputusan-keputusan yang mereka buat akan memberikan keuntungan atau tidak sehingga dapat meningkatkan reputasi mereka sebagai manajer.

Kepemilikan manajerial dapat berpengaruh positif maupun negatif terhadap pengungkapan CSR, karena bergantung pada dasar kepentingan yang dipertimbangkan oleh manajer dalam pengambilan keputusan. Hal ini dapat terkonfirmasi berdasarkan hasil penelitian Nurleni, et al. (2018), yang menemukan bahwa kepemilikan manajerial berpengaruh negatif signifikan terhadap pengungkapan CSR. Sedangkan pengaruh positif dari kepemilikan manajerial terhadap pengungkapan CSR ditemukan dalam penelitian Listyaningsih, et al. (2018), Singal \& Putra (2019) serta Anissa \& Machdar (2019). Berdasarkan teori dan hasil penelitian terdahulu tersebut, maka dapat diajukan hipotesis penelitian sebagai berikut:

H1 : kepemilikan manajerial berpengaruh terhadap pengungkapan CSR

\section{Pengaruh Kepemilikan Institusional terhadap Pengungkapan CSR}

Kepemilikan institusional didefinisikan sebagai sejumlah proporsi saham yang dimiliki oleh institusi. Semakin terkonsentrasi kepemilikan saham dalam suatu perusahaan, maka pengawasan yang dilaksanakan oleh pemilik akan semakin efektif dan efisien sebab manajemen akan semakin berhati-hati bekerja untuk pemilik modal (Sujoko, et al., 2007 dalam Rahma, 2014). Berdasarkan hal tersebut maka dapat diasumsikan bahwa semakin besar kepemilikan institusional, maka akan semakin tinggi pula pengungkapan aktivitas CSR yang dilakukan perusahaan, sebagai bentuk kehati-hatian dalam bekerja. Asumsi ini dapat dikonfirmasi berdasarkan hasil penelitian yang dilakukan oleh Nugroho \& Yulianto (2015), Jaya., Bambang \& Endang (2017), Listyaningsih, et al. (2018), Nurleni, et al. (2018), serta Singal \& Putra (2019), yang menemukan adanya pengaruh positif dan signifikan dari kepemilikan institusional terhadap pengungkapan CSR.

Namun di sisi lain, tindakan monitoring aktif berubah menjadi pasif dan oportunistik ketika kepemilikan saham investor institusional semakin besar. Investor institusional memiliki kekuatan voting yang besar pula untuk berpihak pada pihak manajemen atau bahkan memaksanya untuk mengambil keputusan sesuai dengan kepentingannya dan mengabaikan tujuan meningkatkan nilai perusahaan (Rahma, 2014). Karenanya semakin besar kepemilikan institusional justru berpotensi menurunkan pengungkapan CSR. Hal ini dapat dikonfirmasi dari hasil penelitian Sari \& Rani (2015) maupun Anissa \& Machdar (2019), yang menemukan bahwa kepemilikan institusional berpengaruh negatif signifikan terhadap pengungkapan CSR. Berdasarkan teori dan hasil penelitian terdahulu tersebut, maka dapat diajukan hipotesis penelitian sebagai berikut: $\mathrm{H} 2$ : kepemilikan institusional berpengaruh terhadap pengungkapan CSR 
Berlia Tri Handini dan Padma Adriana Sari: Pengaruh Kepemilikan Manajerial, Institusional dan Komite Audit Terhadap Pengungkapan CSR

\section{Pengaruh Komite Audit terhadap Pengungkapan CSR}

Komite audit bertugas memberikan masukan kepada dewan komisaris atas laporan atau hal-hal yang disampaikan oleh direksi kepada dewan komisaris, mengidentifikasi hal-hal yang memerlukan perhatian komisaris, dan melaksanakan tugas-tugas lain yang berkaitan dengan tugas dewan komisaris (Peraturan Bapepam No. KEP- 29/PM/2004). Tugas dari komite audit ini menunjukkan bahwa peran sentral komite audit sebagai pengawas sistem keuangan dan transparansi pelaporan perusahaan sangat ditentukan oleh keberhasilan komite audit dalam menjalankan tugasnya.

Berdasarkan uraian di atas, dapat diasumsikan bahwa komite audit dapat berpengaruh positif maupun negatif terhadap pengungkapan CSR, karena bergantung pada berhasil tidaknya pelaksanan tugas Komite Audit tersebut. Hal ini dapat terkonfirmasi berdasarkan hasil penelitian Putra \& Rivandi (2019) maupun Iswandika, et al. (2014), yang menemukan bahwa komite audit berpengaruh positif dan signifikan terhadap pengungkapan CSR. Sedangkan pengaruh negatif dari Komite Audit terhadap pengungkapan CSR ditemukan dalam penelitian Rizki, Basri \& Musnadi (2014). Berdasarkan teori dan hasil penelitian terdahulu tersebut, maka dapat diajukan hipotesis penelitian sebagai berikut:

H3 : Komite audit berpengaruh terhadap pengungkapan CSR

Berdasarkan uraian di atas, maka dapat dibentuk suatu kerangka penelitian sebagai berikut:

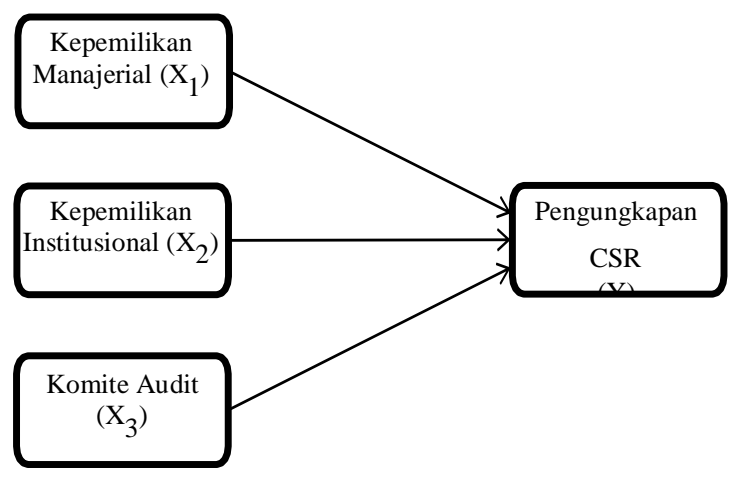

\section{Gambar 1. Kerangka Penelitian}

\section{METODE}

Penelitian ini merupakan penelitian kuantitatif. Data yang digunakan dalam penelitian ini menggunakan data sekunder, yaitu laporan tahunan perusahaan periode tahun 2014 sampai 2018 yang bersumber dari website Bursa Efek Indonesia (idx.co.id). Penelitian ini mengambil populasi 36 perusahaan sektor Consumer Goods Industry yang terdaftar di Bursa Efek Indonesia selama periode 2014-2018. Populasi consumer goods industry dipilih pada penelitian ini karena banyaknya kasus pencemaran lingkungan yang dilakukan oleh perusahaan consumer goods pada beberapa tahun terakhir. Oleh karena itu perlu dilakukan penelitian terkait faktor yang dapat meningkatkan 
Berlia Tri Handini dan Padma Adriana Sari: Pengaruh Kepemilikan Manajerial, Institusional dan Komite Audit Terhadap Pengungkapan CSR

pengungkapan CSR. Penelitian ini menguji pengaruh dari kepemilikan institusional, manajerial dan komite audit terhadap pengungkapan CSR pada industri tersebut.

Sampel penelitian ini dipilih dengan menggunakan teknik purposive sampling. Adapun kriteria perusahaan yang menjadi sampel adalah: Perusahaan yang telah terdaftar di BEI minimal 1 Januari 2014 sebagai awal periode penelitian dan tetap terdaftar hingga akhir periode penelitian 31 Desember 2018; Perusahaan yang selalu mempublikasikan laporan keuangan dan laporan tahunan secara lengkap dan dapat diakses selama periode penelitian 2014- 2018; dan Perusahaan yang secara konsisten memiliki porsi kepemilikan manajerial dan kepemilikan institusional selama selama periode penelitian 2014-2018. Berdasarkan kriteria pengambilan sampel yang digunakan, jumlah perusahaan yang dijadikan sampel penelitian adalah 16 perusahaan.

Peneltian dilakukan dengan beberapa uji statistik yaitu uji normalitas, multikolinieritas, heteroskedastisitas, autokorelasi, dan uji regresi linier berganda. Analisis data dalam penelitian dilakukan untuk mengetahui pengaruh dari variabel bebas kepemilikan manajerial, kepemilikan institusional dan komite audit terhadap pengungkapan CSR.

\section{HASIL DAN PEMBAHASAN}

Pada perusahaan manufaktur sektor consumer goods industry (industri barang konsumsi) terdapat 36 perusahaan terdaftar di Bursa Efek Indonesia pada periode 2014 sampai dengan 2018. Sesuai dengan teknik pengambilan sampel yang digunakan, maka diperoleh 16 perusahaan yang dijadikan sebagai sampel penelitian. Selama periode penelitian tahun 2014 sampai dengan 2018, jumlah data amatan adalah 80 .

Uji asumsi klasik telah dilakukan pada data amatan. Hasil uji tersebut adalah data telah terdistibusi normal, tidak ditemukan adanya multikolinieritas, dan juga tidak terjadi masalah heteroskedastisitas. Selanjutnya, berdasarkan hasil uji koefisien determinasi diperoleh nilai adjusted $\mathrm{R}$ square sebesar 0,518 . Hal ini dapat diartikan bahwa variabel dependen dalam penelitian dapat dijelaskan oleh variabel independen sebesar 51,8\%. Sedangkan sisanya sebesar $48,2 \%$ dijelaskan oleh variabel lain yang tidak dijelaskan dalam penelitian ini.

Berdasarkan temuan yang diperoleh dari hasil analisis regresi berganda. Maka, dapat diketahui hasil hipotesis parsial (uji t) dan simultan (uji F) yang digambarkan seperti tabel berikut ini:

Tabel 1. Hasil Uji Parsial (Uji t)

\begin{tabular}{cccc}
\hline Variabel & T hitung & Signifikansi & Keputusan \\
\hline $\begin{array}{c}\text { Kepemilikan } \\
\text { Manajerial }\end{array}$ & 0,113 & 0,910 & $\mathrm{H} 1$ ditolak \\
\hline $\begin{array}{c}\text { Kepemilikan } \\
\text { Institusional }\end{array}$ & 2,596 & 0,011 & $\mathrm{H} 2$ diterima \\
\hline Komite Audit & 3,888 & 0,000 & $\mathrm{H} 3$ diterima \\
\hline
\end{tabular}


Berlia Tri Handini dan Padma Adriana Sari: Pengaruh Kepemilikan Manajerial, Institusional dan Komite Audit Terhadap Pengungkapan CSR

Sumber: Hasil Analisis (2020)

\section{Pengaruh Kepemilikan Manajerial terhadap Pengungkapan CSR}

Hasil pengujian hipotesis menggunakan uji $\mathrm{t}$ menunjukkan bahwa koefisien kepemilikan manajerial memiliki nilai positif sebesar 0,113 pada tingkat signifikansi 0,910 yang lebih besar dari 5\%. Berdasarkan hasil tersebut, maka hipotesis 1 yang menyatakan bahwa kepemilikan manajerial berpengaruh terhadap pengungkapan CSR pada perusahaan sektor consumer goods industry yang terdaftar di Bursa Efek Indonesia Tahun 2014-2018 dinyatakan ditolak.

Berdasarkan hasil penelitian ini dapat dijelaskan bahwa besar kecilnya kepemilikan saham oleh manajemen perusahaan manufaktur sektor consumer goods industry yang terdaftar di BEI selama periode 2014-2018, tidak memberikan pengaruh terhadap pengungkapan CSR yang dilakukan perusahaan. Hal ini dimungkinkan terjadi karena nilai kepemilikan manajerial dalam penelitian ini yang sangat kecil, sehingga tidak memiliki cukup pengaruh terhadap pengungkapan CSR yang dilakukan perusahaan.

Data menunjukkan bahwa nilai rata-rata kepemilikan manajerial dari perusahaan yang diteliti selama periode penelitian hanya sebesar 6,69\%, sangat jauh dibandingkan rata-rata kepemilikan institusional yang sebesar $66,18 \%$. Hasil tersebut mendukung hasil penelitian Sari \& Rani (2015) yang juga tidak menemukan adanya pengaruh signifikan dari kepemilikan manajerial terhadap pengungkapan CSR. Namun hasil penelitian ini berbeda dengan hasil penelitian Listyaningsih, et al. (2018), Anissa \& Machdar (2019), serta Singal \& Putra (2019) yang menemukan adanya pengaruh positif signifikan dari kepemilikan manajerial terhadap pengungkapan CSR. Demikian pula dengan penelitian Nurleni, et al. (2018), yang menemukan adanya pengaruh negatif signifikan dari kepemilikan manajerial terhadap pengungkapan CSR.

\section{Pengaruh Kepemilikan Institusional terhadap Pengungkapan CSR}

Hasil penelitian ini membuktikan asumsi bahwa kepemilikan institusional berpengaruh positif terhadap pengungkapan CSR. Hal ini dibuktikan dengan hasil pengujian hipotesis menggunakan uji t yang menunjukkan bahwa koefisien kepemilikan institusional memiliki nilai positif sebesar 2,596 pada tingkat signifikansi 0,011 yang lebih kecil dari 5\%. Berdasarkan hasil tersebut, maka hipotesis 2 yang menyatakan bahwa kepemilikan institusional berpengaruh terhadap pengungkapan CSR pada perusahaan sektor consumer goods industry yang terdaftar di Bursa Efek Indonesia Tahun 2014-2018 dinyatakan diterima.

Berdasarkan hasil penelitian tersebut dapat dijelaskan bahwa besar kecilnya kepemilikan saham perusahaan manufaktur sektor consumer goods industry yang terdaftar di BEI selama periode 2014-2018 oleh institusi di luar perusahaan, dapat meningkatkan pengungkapan CSR yang dilakukan perusahaan. Hasil ini dapat dijelaskan dengan data penelitian yang menunjukkan bahwa besarnya kepemilikan institusional pada perusahaan-perusahaan yang diteliti, yang rata-ratanya mencapai $66,18 \%$. Hal ini sesuai dengan pendapat yang menyebutkan bahwa semakin terkonsentrasi kepemilikan saham dalam suatu perusahaan, maka pengawasan yang dilaksanakan oleh pemilik akan 
Berlia Tri Handini dan Padma Adriana Sari: Pengaruh Kepemilikan Manajerial, Institusional dan Komite Audit Terhadap Pengungkapan CSR

semakin efektif dan efisien sebab manajemen akan semakin berhati-hati bekerja untuk pemilik modal (Sujoko, et al., 2007 dalam Rahma, 2014).

Hasil penelitian ini mendukung hasil penelitian Nugroho \& Yulianto (2015), Jaya, et al. (2017), Listyaningsih, et al. (2018), Nurleni, et al. (2018) serta Singal \& Putra (2019) yang semuanya juga menemukan adanya pengaruh positif signifikan dari kepemilikan institusional terhadap pengungkapan CSR. Namun hasil penelitian ini berbeda dengan hasil penelitian Sari \& Rani (2015) dan Anissa \& Machdar (2019) yang justru menemukan adanya pengaruh negatif signifikan dari kepemilikan institusional terhadap pengungkapan CSR. Demikian pula dengan penelitian Iswandika, et al. (2014) yang tidak menemukan adanya pengaruh signifikan dari kepemilikan institusional terhadap pengungkapan CSR.

\section{Pengaruh Komite Audit terhadap Pengungkapan CSR}

Hasil penelitian ini membuktikan asumsi bahwa komite audit berpengaruh positif terhadap pengungkapan CSR. Hal ini dibuktikan dengan hasil pengujian hipotesis menggunakan uji $\mathrm{t}$ yang menunjukkan bahwa koefisien komite audit memiliki nilai positif sebesar 3,888 pada tingkat signifikansi 0,000 yang lebih kecil dari 5\%. Berdasarkan hasil ini, maka hipotesis 3 yang menyatakan bahwa komite audit berpengaruh terhadap pengungkapan CSR pada perusahaan sektor consumer goods industry yang terdaftar di Bursa Efek Indonesia Tahun 2014-2018 dinyatakan diterima.

Berdasarkan hasil penelitian tersebut dapat dijelaskan bahwa ukuran komite audit yang sesuai dengan aturan yang ditetapkan pada perusahaan manufaktur sektor consumer goods industry yang terdaftar di BEI selama periode 2014-2018, dapat meningkatkan pengungkapan CSR yang dilakukan perusahaan. Hasil ini dapat dijelaskan dengan data penelitian yang menunjukkan bahwa komite audit pada perusahaan-perusahaan yang diteliti, mayoritas sudah terdiri sekurangnya 3 orang dan bahkan sebagian ada yang lebih, sehingga skor rata-rata dari variabel komite audit besarnya mencapai 0,93 . Hal ini juga membuktikan peran sentral komite audit sebagai pengawas sistem keuangan dan transparansi pelaporan perusahaan yang ditentukan oleh keberhasilan komite audit dalam menjalankan tugasnya.

Hasil penelitian ini mendukung hasil penelitian Iswandika, et al. (2014) dan Putra \& Rivandi (2019) yang menemukan adanya pengaruh positif signifikan dari komite audit terhadap pengungkapan CSR. Namun hasil penelitian ini berbeda dengan hasil penelitian Rizki, et al. (2014) yang justru menemukan adanya pengaruh negatif signifikan dari komite audit terhadap pengungkapan CSR. Demikian pula dengan penelitian Nugroho \& Yulianto (2015) dan Listyaningsih, et al. (2018) yang tidak menemukan adanya pengaruh signifikan dari komite audit terhadap pengungkapan CSR

Hasil penelitian ini menunjukkan bahwa kepemilikan institusional dan komite audit dapat berpengaruh positif signifikan terhadap pengungkapan CSR. Artinya semakin besar porsi kepemilikan saham oleh institusi di luar perusahaan, maupun ukuran komite audit, maka akan semakin banyak indikator pengungkapan CSR menurut GRI G4, yang diungkapkan oleh perusahaan. Oleh karenanya besar kecilnya porsi 
Berlia Tri Handini dan Padma Adriana Sari: Pengaruh Kepemilikan Manajerial, Institusional dan Komite Audit Terhadap Pengungkapan CSR

kepemilikan saham institusional dan ukuran komite audit perlu mendapatkan perhatian karena pengaruhnya terhadap pengungkapan CSR tersebut.

Hasil penelitian ini di harapkan bisa membantu untuk memberi masukan kepada investor yang hendak melakukan investasi pada perusahaan-perusahaan manufaktur yang terdaftar di BEI, khususnya pada sektor industri barang konsumsi. Karena seperti diketahui bahwa pengungkapan CSR atau tanggung jawab sosial yang dilakukan oleh perusahaan akan dapat berdampak kepada nilai perusahaan. Corporate Sosial Responsibility (CSR) merupakan komitmen perusahaan untuk mendukung sustainable development. Semangat CSR diharapkan mampu menciptakan keseimbangan antara perusahaan, masyarakat dan lingkungannya.

\section{KESIMPULAN}

Berdasarkan analisis hasil penelitian dan pembahasan yang telah dikemukakan, dari 16 perusahaan sektor consumer goods industry yang terdaftar di Bursa Efek Indonesia selama periode 2014-2018 dapat ditarik kesimpulan bahwa kepemilikan manajerial tidak berpengaruh signifikan terhadap pengungkapan corporate social responsibility (CSR) perusahaan sektor consumer goods industry yang terdaftar di Bursa Efek Indonesia periode 2014-2018. Hal ini dapat disebabkan karena nilai kepemilikan manajerial dalam penelitian ini rata-rata sangat kecil, sehingga tidak memberikan dampak terhadap keputusan pengungkapan CSR.

Kepemilikan institusional berpengaruh positif signifikan terhadap pengungkapan corporate social responsibility (CSR) perusahaan sektor consumer goods industry yang terdaftar di Bursa Efek Indonesia periode 2014-2018. Porsi kepemilikan institusional yang rata-ratanya cukup tinggi dalam penelitian tentu akan memantau perkembangan investasinya dan mendorong manajemen perusahaan untuk melakukan aktivitas yang positif termasuk pengungkapan CSR. Kesimpulan selanjutnya adalah komite audit berpengaruh positif signifikan terhadap pengungkapan corporate social responsibility (CSR) perusahaan sektor consumer goods industry yang terdaftar di Bursa Efek Indonesia periode 2014-2018. Jumlah komite audit yang dalam penelitian ini hampir seluruhnya telah sesuai aturan yaitu minimal 3 orang, dan keberadaannya efektif dalam membantu pelaksanaan transparansi perusahaan, termasuk dalam hal pengungkapan CSR dalam laporan tahunan.

Berdasarkan tujuan penelitian dan kesimpulan diatas beberapa saran yang dapat diberikan yaitu Bursa Efek Indonesia (BEI) dan Otoritas Jasa Keuangan (OJK) perlu merancang suatu peraturan yang lebih ketat tentang standar pengungkapan CSR oleh perusahaan- perusahaan yang terdaftar di Bursa Efek Indonesia. Hal ini diperlukan untuk meningkatkan kesadaran manajemen perusahan untuk mengembangkan dan mengimplementasikan kebijakan serta prosedur untuk meminimalisasi berbagai kerusakan atau kerugian yang mungkin dihasilkan dari operasi perusahaan. Dengan meningkatnya kesadaran tersebut diharapkan nilai sosial positif dari perusahaan akan meningkat di mata para stakeholder, khususnya dari kalangan masyarakat luas, yang juga akan berdampak positif pada kelangsungan operasional perusahaan. 
Berlia Tri Handini dan Padma Adriana Sari: Pengaruh Kepemilikan Manajerial, Institusional dan Komite Audit Terhadap Pengungkapan CSR

Disarankan untuk penelitian selanjutnya agar lebih memperluas obyek penelitian dengan menambah jumlah sampel penelitian di luar kelompok perusahaan yang diteliti dalam penelitian ini. Selain itu juga perlu ditambah rentang waktu periode penelitian untuk melihat adanya pengaruh dari variabel bebas terhadap variabel terikatnya. Hal ini diperlukan karena dimungkinkan akan dapat diperoleh hasil yang berbeda dengan hasil penelitian ini maupun dengan hasil penelitian-penelitian terdahulu, mengingat research gap yang terjadi antara penelitian ini dengan penelitian-penelitian terdahulu. Selain itu juga perlu ditambahkan variabel lain yang dapat mempengaruhi pengungkapan CSR, seperti kinerja keuangan perusahaan, ukuran dewan komisaris, dan lain sebagainya. Karena dari banyak variabel yang pernah diteliti dalam penelitian terdahulu, penelitian ini hanya meneliti tiga varibel, dan terbukti hanya dua diantaranya yang terbukti berpengaruh terhadap pengungkapan CSR.

\section{DAFTAR PUSTAKA}

Ahmed, H.J.A. 2009. “Managerial Ownership Concentration And Agency Conflict Using Logistic Regression Approach: Evidence From Bursa Malaysia". Journal of Management Research. Vol. 1, No. 1, pp. 1-10.

Anissa, C.D. \& Machdar, N.M. 2019. “Pengaruh Kepemilikan Institusional, Kepemilikan Manajerial dan Profitabilitas terhadap Pengungkapan Tanggung Jawab Sosial Perusahaan". Kalbisocio. Vol. 6, No. 1, pp. 9-18

Bawono, A.A.K. \& Haryanto. 2015. "Pengaruh Ukuran Perusahaan, Leverage, Profitabilitas, Cakupan Operasional Perusahaan, Dan Sertifikasi ISO 14001 Terhadap Pengungkapan Corporate Social Responsibility (Studi pada Perusahaan Manufaktur yang Terdaftar di BEI Tahun 2012-2013)". Diponegoro Journal Of Accounting. Vol. 4, No. 5, pp. 2337-3806

Bernandhi, R. \& Muid, A. 2014. "Pengaruh Kepemilikan Manajerial, Kepemilikan Institusional, Kebijakan Dividen, Leverage, Dan Ukuran Perusahaan Terhadap Nilai Perusahaan". Diponegoro Journal Of Accounting. Vol. 3, No. 1, pp. 1-14

Erawati, T. \& Sari, L. 2021. "Pengaruh Kepemilikan Manajerial, Ukuran Perusahaan, Manajemen Laba dan Komite Audit Terhadap Pengungkapan CSR". Jurnal Analisa Akuntansi dan Perpajakan, Vol. 5, No. 1, Maret 2021, Hlm 45-49.

Heriyanto. 2020. Limbah Pabrik Belum Ditangani Serius. Berita Satu. https://www.beritasatu.com/nasional/698449/limbah-pabrik-belum-ditanganiserius. Diakses tanggal 1 Mei 2021.

Iswandika, R., Murtanto \& Sipayung, E. 2014. "Pengaruh Kinerja Keuangan, Corporate Governance, Dan Kualitas Audit Terhadap Pengungkapan Corporate Social Responsibility". e-Journal Akuntansi Fakultas Ekonomi Universitas Trisakti. Vol. 1, No. 2, pp. 1-18

Jaya, S.M.A., Bambang, P. \& Endang, M. 2017. “The Effect of Corporate Governance Mechanism, Ownership Structure, and External Auditor Toward Corporate Social Responsibility Disclosure With Earning Management as Moderating Variable". 
Berlia Tri Handini dan Padma Adriana Sari: Pengaruh Kepemilikan Manajerial, Institusional dan Komite Audit Terhadap Pengungkapan CSR

RJOAS: Russian Journal of Agricultural and Socio-Economic Sciences. Vol. 8, No. 68, pp. 41-52

Listyaningsih, E., Dewi, R. \& Baiti, N. 2018. “The Effect of Good Corporate Governance on Corporate Social Responsibility Disclosure on Jakarta Islamic Index". Indonesian Journal of Business and Entrepreneurship. Vol. 4, No. 3, pp. 273-281

Mardikanto, T. 2014. CSR (Corporate Social Responsibility): Tanggungjawab Sosial Korporasi. Bandung: Alfabeta

Nugroho, M.N. \& Yulianto, A. 2015. “Pengaruh Profitabilitas dan Mekanisme Corporate Governance Terhadap Pengungkapan CSR Perusahaan Terdaftar JII 2011-2013". AAJ: Accounting Analysis Journal. Vol. 4, No. 1, pp.1-12

Nurleni, N., Bandang, A., Darmawati, \& Amiruddin, A. (2018). The effect of managerial and institutional ownership on corporate social responsibility disclosure. International Journal of Law and Management, 00-00. doi:10.1108/ijlma-03-20170078

Purwanto, A. 2011. "Pengaruh Tipe Industri, Ukuran Perusahaan, Profitabilitas, Terhadap Corporate Social Responsibility". Jurnal Akuntansi \& Auditing. Vol. 8, No. 1, pp. 1229

Putra, A.H. \& Rivandi, M. 2019. “Pengaruh Dewan Komisaris Dan Komite Audit Terhadap Pengungkapan Corporate Social Responsibility (Studi Empiris Perusahaan High Profile Di Bursa Efek Indonesia)". Academic Conference of Accounting I. Vol. 1, pp. 76-93

Rahma, A. 2014. “Pengaruh Kepemilikan Manajerial, Kepemilikan Institusional, Dan Ukuran Perusahaan Terhadap Keputusan Pendanaan Dan Nilai Perusahaan (Studi Kasus Pada Perusahaan Manufaktur yang Terdaftar di Bursa Efek Indonesia Periode 2009-2012)". Jurnal Bisnis Strategi. Vol. 23, No. 2, pp. 45-69

Riady, E. 2020. Pencemaran Sungai Dampak Limbah Pabrik Susu, Ini Kata Dinas Lingkungan Hidup. Detik News Berita Jawa Timur. https://news.detik.com/beritajawa-timur/d-4858046/pencemaran-sungai-dampak-limbah-pabrik-susu-ini-katadinas-lingkungan-hidup/1. Diakses tanggal 1 Mei 2021.

Riyadi, M. 2019. CEO Perusahaan Consumer Goods "Diadili"di Davos Karena Sampah Plastik. Villagerspost.com. https://villagerspost.com/todays-feature/ceoperusahaan-consumer-goods-diadili-di-davos-karena-sampah-plastik. Diakses tanggal 1 Mei 2021.

Rizki, L.A., Basri, H. \& Musnadi, S. 2014. “Pengaruh Faktor Fundamental Dan Mekanisme Corporate Governance Terhadap Pengungkapan Corporate Social Responsibility Pada Perusahaan Manufaktur Yang Terdaftar Di Bursa Efek 
Berlia Tri Handini dan Padma Adriana Sari: Pengaruh Kepemilikan Manajerial, Institusional dan Komite Audit Terhadap Pengungkapan CSR

Indonesia". Jurnal Magister Akuntansi Pascasarjana Universitas Syiah Kuala. Vol. 3, No. 3, $p p$. 35- 45

Sari, W.N. \& Rani, P. 2015. "Pengaruh Kepemilikan Institusional, Kepemilikan Manajerial, Return On Assets (ROA) Dan Ukuran Perusahaan Terhadap Pengungkapan Corporate Social Responsibility (CSR) Pada Perusahaan Manufaktur Yang Terdaftar Di Bursa Efek Indonesia Periode 2011-2013". Jurnal Akuntansi dan Keuangan FE Universitas Budi Luhur. Vol. 4, No. 1, pp. 1-20

Singal, P.A. \& Putra, I.N.W.A. 2019. "Pengaruh Kepemilikan Institusional, Kepemilikan Manajerial, dan Kepemilikan Asing Pada Pengungkapan Corporate Social Responsibility". E-JA : e-Jurnal Akuntansi. Vol. 298, No. 1, pp. 468-484

Sugiarto. 2009. Struktur Modal ,Struktur Kepemilikan Perusahaan, Permasalahan Keagenan dan Informasi Asimetri. Yogyakarta: Graha Ilmu

Suharto, E. 2010. CSR \& COMDEV: Investasi Kreatif Perusahaan di Era Globalisasi. Bandung: Alfabeta

Untung, H.B. 2008. Corporate Social Responsibility. Jakarta: Sinar Grafika 